\title{
Evaluating the impacts of $\mathrm{SO}_{2}$ emissions from power stations in Kuwait
}

\author{
M. M. Al-Awadhi ${ }^{1} \&$ M. F. Yassin ${ }^{2}$ \\ ${ }^{1}$ The Public Authority for Applied Education \& Training, Kuwait \\ ${ }^{2}$ Department of Environmental Technology Management, \\ College for Women, Kuwait University, Kuwait
}

\begin{abstract}
The AERMOD-ISC dispersion model has been used to study the impact $\mathrm{SO}_{2}$ emitted from power stations in Kuwait. $\mathrm{SO}_{2}$ emissions from fifteen stacks were studied to evaluate the pollutant dispersion patterns and the risk of nearby populations being negatively affected by such emission. One year's meteorological data was used for simulating the ground level concentrations of $\mathrm{SO}_{2}$. The level was estimated based on a model simulating the concentration on an hourly, daily and annual basis. The air quality was monitored at four different residential areas over the course of a year. The simulated concentrations were validated by comparing them with the observed values at four locations in residential areas. The results demonstrated that there is a great similarity in the simulated concentrations with observed values. The model performance was also found to be satisfactory. The hourly and daily concentrations of the simulated model exceeded the KW-EPA limits. This indicates that there is a significant influence of $\mathrm{SO}_{2}$ emission from the power station in ambient air quality.
\end{abstract}

Keywords: air quality, dispersion model, AREMOD, meteorological data, sulfur dioxide.

\section{Introduction}

The deterioration of air quality in urban areas has been shown to be linked to serious health problems. Pollutants such as sulfur dioxide gas $\left(\mathrm{SO}_{2}\right)$ of power stations can have serious health effects if the ambient concentration in the air reaches high levels. In order to understand the impact of such $\mathrm{SO}_{2}$ emissions, mathematical models are commonly used to predict the temporal and spatial 
distribution of $\mathrm{SO}_{2}$ emissions in urban areas. In addition to using models for research applications, air quality models are also employed for conducting environmental assessments and formulating decisions to manage urban air pollution.

The dispersion of $\mathrm{SO}_{2}$ emissions using experimental field and air quality models of Gaussian-type have been studied for different cities in the world. In this regard Pruchnicki [1] discussed air pollution models as used in regional development planning in Poland, and described the air quality standards currently in effect. Patil and Patil [2] estimated the quantitative air quality impact assessment score for a thermal power plant. Emission factors and annual emissions of bulk and trace elements from oil-shale-fueled power plants have been investigated by Hosanna et al. [3]. Gouveiaa et al. [4] used a numerical model to study the impact of urban air pollution from Setúbal City on two important natural reserves. Villegas et al. [5] simulated the dispersion of $\mathrm{SO}_{2}$, $\mathrm{NO}_{\mathrm{x}}$ and primary $\mathrm{PM}_{10}$ emissions from power plant stacks and the formation of secondary particulate matter using the CALPUFF Lagrangian puff model (Earth Tech, Concord, MA). Palau et al. [6] described the atmospheric dispersion of the emissions from a power plant with a 343-meter-tall chimney, situated on very complex terrain in the North-East of Spain, under winter conditions. Bhanarkar et al. [7] presented a prediction of the impact on air quality of two naphthanatural gas fired combined cycle power plants having identical air emissions but located in a coastal area and in an inland area, which have considerable variation in topography and meteorology. Lopez et al. [8] studied the health impact of power plant emissions in Mexico. Rodriguez et al. [9] studied the air quality impact of distributed power generated in the south coast air basin of California, USA. Their study focused on two main objectives: (1) the systematic characterization of distributed power generated installation in urban air basins, and (2) the simulation of potation air quality impact using a state-of-the art threedimensional computational model. Racoceanu and Diaconu et al. [10] studied the pollutants dispersion emitted from power plants and identified the areas affected by pollutants emissions as well as the areas in which concentrations of pollutants are beyond the legal limits. Racoceanu and Capatina et al. [11] simulated and analyzed the cross-boundary pollution due to the activity of the thermal power station of Turceni using the ISC for evaluating the pollutant dispersion. Yousif et al. [12] have conducted theoretical investigations of pollutants dispersion, $\mathrm{NO}_{\mathrm{x}}$, $\mathrm{SO}_{2}$ and Particulate Matter (PM), from stacks of four arbitrary power plants in Libya using the Gaussian Plume model. Khlaifi et al. [13] presented a study focuses on the source inversion based on a simple Gaussian Dispersion model, coupled originally with a genetic algorithm. This approach was developed and tested on real data. Demael and Carissimo et al. [14] presented a comparison for the modeling of flow and dispersion on the built up area of a nuclear power plant through the study of two types of releases. A CFD model developed by CEREA/ EDF R\&D is compared to ADMS simulations against wind-tunnel measurements. Kho et al. [15] used the ISC-AERMOD dispersion model to predict air dispersion plumes from a diesel power plant complex. Emissions of $\mathrm{NO}_{2}$ and $\mathrm{SO}_{2}$ from stacks (total of 5) and a waste oil incinerator were studied to 
evaluate the pollutant dispersion patterns and the risk of a nearby population. Yousefi et al. [16] presented an assessment of the potential impacts on air quality of the utilization of the Sabalan geothermal power plant in northwestern Iran. The prediction distributions of $\mathrm{H}_{2} \mathrm{~S}$ after the utilization of the geothermal power plant (GPP) were modeled using the Industrial Source Complex Model (ISC3View). Tuaycharoen et al. [17] simulated the concentrations and dispersions of nitrogen oxides emitted from Khanom Power Plant, located in the southern part of Thailand, using the Regional Atmospheric Modeling System (RAMS) coupled with the CALMET-CALPUFF models. These studies reveal the importance of the application of mathematical models for air quality management studies due to the $\mathrm{SO}_{2}$ emission of the power stations in urban areas.

The state of Kuwait is located in the Arabian Gulf. It has a hot dry climate and consists of large uninhabited desert area, with the temperature varying between $40^{\circ} \mathrm{C}$ and $50^{\circ} \mathrm{C}$ for at least six months of the year. Therefore, the thermal stratification stability affects the contaminant diffusion in the atmospheric boundary layer within the state of Kuwait. In addition, the changing wind direction affects the pollutant dispersion. Generally, when effluents are released from a vertical stack possessing a lot of momentum or at high vertical velocity, the effluent plume is not drawn down in the low pressure region in the proximity of wake of the stack.

A number of studies in Kuwait have been conducted to estimate $\mathrm{SO}_{2}$ emissions of the power stations, e.g. Bouhamra and Abdul-Wahab et al. [18] who presented a statistical analysis of the data collected by an air pollution mobile laboratory operated by Kuwait University. The experimental work was based on operating the mobile laboratory in the Mansouriya residential area for a period of one month. Ramadan et al. [19] presented results obtained using the Industrial Sources Complex Short Term (ISCST3) model to calculate the $\mathrm{SO}_{2}$ concentration resulting from existing power stations in Kuwait. It assumes a zero background $\mathrm{SO}_{2}$ concentration and an entire reliance on Heavy Fuel Oil. AlAzmi et al. [20] used the Source Complex model for Short-term Dispersion (ISCST4.5) to predict ambient ground level concentrations of $\mathrm{SO}_{2}$ and $\mathrm{NO}_{\mathrm{x}}$ emitted from power stations at selected receptors in Kuwait.

In the present study, the impact of Doha East and Doha West power stations on the ambient air quality in Kuwait was examined using the AERMOD-ISC dispersion model. To conduct this, $\mathrm{SO}_{2}$ emission rate of Doha East and Doha West power stations for one year was used in parallel with the meteorological data. Four different air quality monitoring stations (AQMS) were used at Mutla, Jahra, Rabia and Mansouriya residential areas in order to measure the concentration level of $\mathrm{SO}_{2}$. The objective of the present study was to estimate the atmospheric levels of $\mathrm{SO}_{2}$ emissions. These could be compared against the KWEPA (Kuwait Environment Public Authority) Ambient Air Quality Standards which sets the international standard for the $\mathrm{SO}_{2}$ emissions in urban areas. For model validation purposes, the simulated results are compared to field data collected over a period of a year. 


\section{Area description}

Doha East and Doha West power stations were considered as the two power stations affecting the air quality over the residential areas the most in Kuwait. Fig. 1 shows the Kuwait map and the location of the Doha East and Doha West power stations relative to Kuwait city and other areas in Kuwait. The two power stations are situated in Doha, located approximately $15 \mathrm{~km}$ to the west of Kuwait city as shown in Fig. 1. Doha East and Doha West power stations are designed to operate using different types of fuel (mixed firing option), including gas and liquid oil products such as natural gas, heavy fuel oil (HFO), crude oil and gas oil.

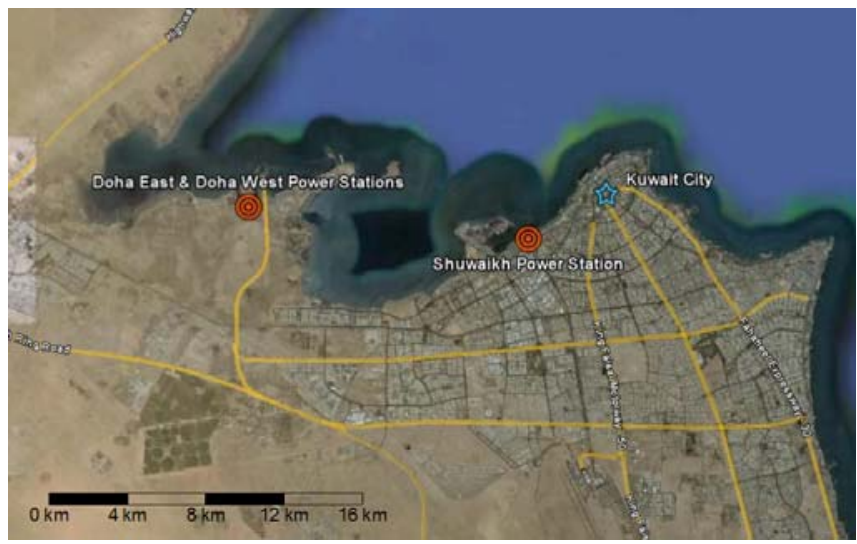

Figure 1: $\quad$ Doha East and Doha West power stations location.

One of the most important properties of fossil fuel is their sulfur content. $\mathrm{SO}_{2}$ is produced by burning of fossil fuels. The $\mathrm{SO}_{2}$ emissions are directly proportional to the sulfur content in the fuel, and the quantity of fuel consumed. Therefore, the accuracy of the $\mathrm{SO}_{2}$ estimates depends on the degree of precision with which sulfur content in the fuel is reported.

Both Doha East and Doha West power stations have two chimneys. Each chimney of Doha West contains four stacks. Doha East differs slightly, as it contains four stacks in the one chimney and three stacks in the other. The emissions from these power stations are a cause for major concern in terms of the deteriorating ambient air quality. It is therefore necessary to study the impact of the residential area on the ambient air quality in and around the surrounding power stations region. The dispersion of a common pollutant $\mathrm{SO}_{2}$ that is being emitted from Doha East and Doha West power stations were examined in this study. 


\section{Data acquisition}

\subsection{Meteorological data}

The meteorological parameters data input for this modeling was obtained from the surface weather observatory station at Kuwait International Airport, and it was assumed to be representative of the meteorological data of the entire Kuwait. A detailed analysis of the meteorological data such as ceiling height, wind speed, wind direction, air temperature, total cloud opacity and total cloud amount has been made over year 2008 .

A fair estimate of the dispersion of pollutants in the atmosphere is based on the frequency of the distribution of wind direction as well as the wind speed. Fig. 2 illustrates the hourly wind rose diagram for year 2008. The prevailing wind direction was from northwest and comprised $45 \%$ of all hourly wind directions.

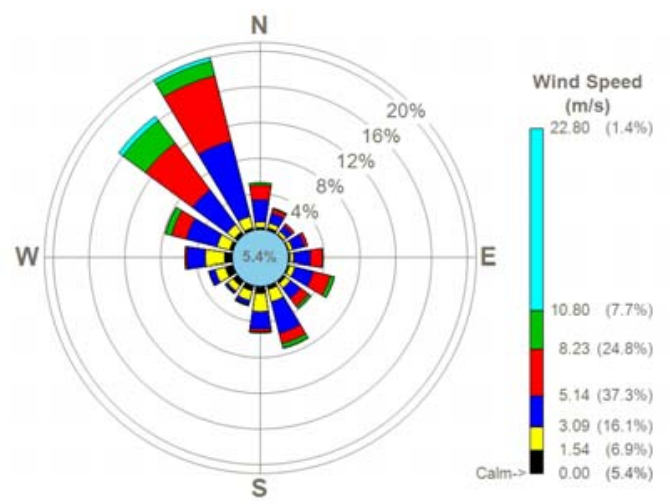

Figure 2: $\quad$ Hourly wind data for Kuwait, year 2008.

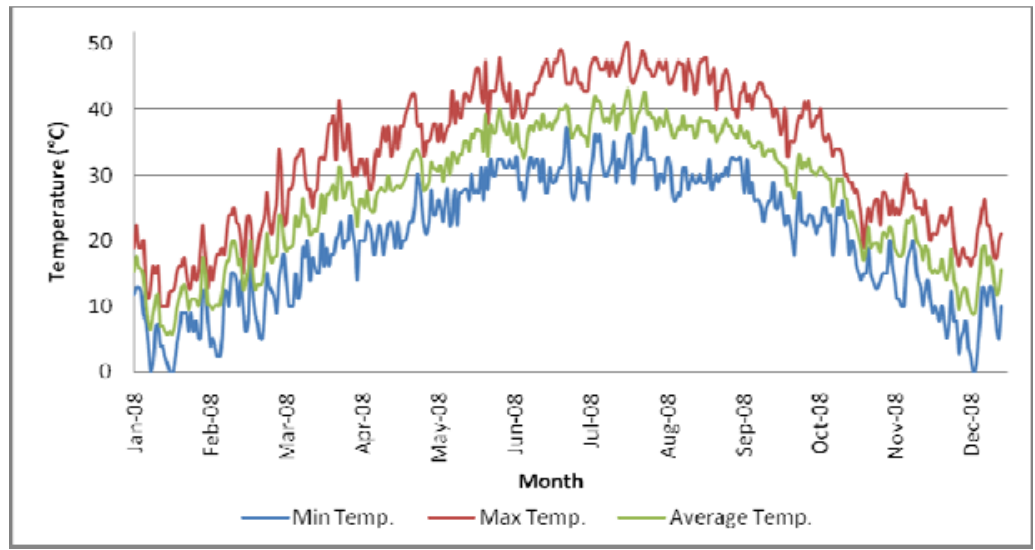

Figure 3: $\quad$ Temperature variation during 2008. 
The temperature fluctuation in Kuwait is quite diverse. This is ascribed to Kuwait being affected by thermal stability. The minimum recorded temperature for 2008 was $-1{ }^{\circ} \mathrm{C}$ in January and the maximum was $51^{\circ} \mathrm{C}$ in July which is illustrated in Fig. 3. Thus in the present study, the meteorological data of the wind speed, wind direction, temperature, atmospheric stability and mixing height and some other parameters have been used in the numerical dispersion model.

\subsection{AQMS (Air quality monitoring stations)}

The current status of air quality within the study domain was determined by on site ground level measurement. Ground level measurement of pollutants at 4 sites within the domain coverage was established. The AQMS are situated at strategic locations mainly in residential areas as well as institutional and industrial sites as illustrated in Fig. 4. The measured data of the $\mathrm{SO}_{2}$ ground level concentration of the AQMS were used to validate the simulated value from the dispersion Model. $\mathrm{SO}_{2}$ concentration data was recorded hourly for a period of one year, January to December 2008, using AQMS at four locations: Mutla, Jahra, Rabia and Mansouriya residential areas in Kuwait (Fig. 4). The locations where the quality of the air was monitored were selected as the sample site on the basis of the availability of electricity and security as well as the topography of the area.

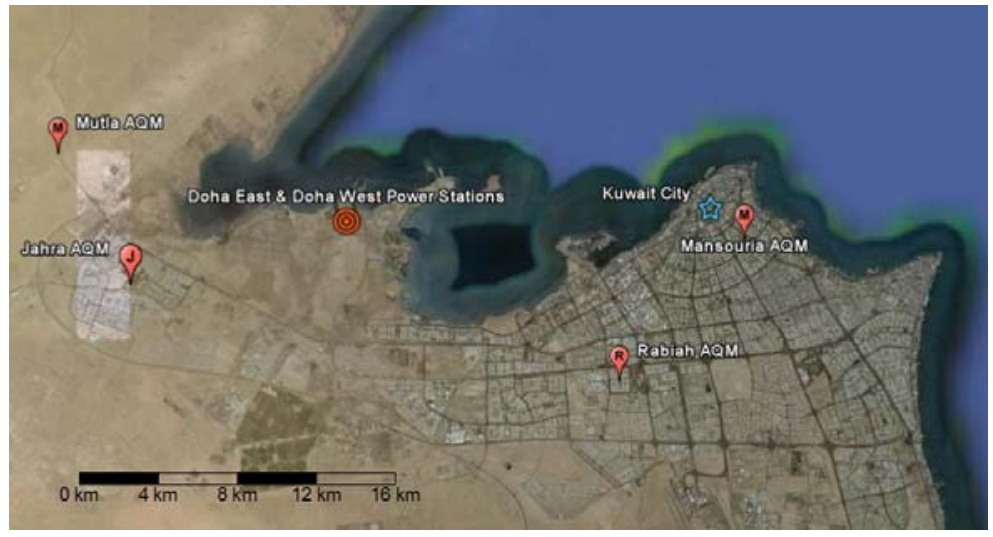

Figure 4: $\quad$ Four AQMS (Air quality monitoring stations).

\section{Description of dispersion model}

The AERMOD-ISC dispersion model (AMS/EPA Regulatory Model - Industrial Source Complex) is an advanced new-generation model developed by the U.S. EPA and serves as a complete replacement for ISC3. It is designed to predict pollutant concentration as well as the extent of deposits over a short-range (up to 50 kilometers) dispersion of air pollutant emissions from an industrial source complex. AERMOD-ISC features an integrated Geographical Information 
System (GIS) as well as intuitive data analysis interface tools that enable modeled objects and results to interact and be displayed alongside a variety of geophysical data.

Therefore, AERMOD-ISC was carried out to facilitate estimation of ground level concentration of $\mathrm{SO}_{2}$ emitted from the Doha East and Doha West power stations. The study domain has been set to cover area of $50 \mathrm{~km} \mathrm{X} 50 \mathrm{~km}$, by representing the Doha East and Doha West power stations in the center of this area. The grid base elements are a square with sides the length of $1000 \mathrm{~m}$. The domain includes 2601 receptors. Four discrete receptors were represented as the four air quality monitoring stations (AQMS).

\section{Results and discussions}

The AERMOD-ISC model has been used to simulate the ground level concentrations of $\mathrm{SO}_{2}$ released from fifteen stacks at the Doha East and Doha West power stations. The model was run according to the input data (emission source, meteorological and receptor parameters) to simulate hourly, daily and annual averaged distributions of the ground level concentrations of $\mathrm{SO}_{2}$ during the year 2008. KW-EPA has defined the maximum hourly, daily and annual average concentration limits of $\mathrm{SO}_{2}$ in the ambient air quality standards. Table 1 shows the KW-EPA ambient air quality standards for residential areas. These standards were followed in the current study to determine $\mathrm{SO}_{2}$ violations.

Table 1: $\quad$ K-EPA ambient air quality standards for residential areas.

\begin{tabular}{|c|c|c|c|c|c|c|}
\hline Time & \multicolumn{2}{|c|}{ Hour* } & \multicolumn{2}{c|}{ Day** } & \multicolumn{2}{c|}{ Year } \\
\hline \multirow{3}{*}{$\mathrm{SO}_{2} * * *$} & $\mathrm{ppb}$ & $\mu \mathrm{g} / \mathrm{m}^{3}$ & $\mathrm{ppb}$ & $\mu \mathrm{g} / \mathrm{m}^{3}$ & $\mathrm{ppb}$ & $\mu \mathrm{g} / \mathrm{m}^{3}$ \\
\cline { 2 - 7 } & 170 & 444 & 60 & 157 & 30 & 80 \\
\hline
\end{tabular}

* Average hour not to occur more than twice during the period of 30 days on the same site.

** Daily average (24 hours) should not occur more than once during the year. *** Should apply in residential dominated areas that lie on the border of industrial areas.

\subsection{Validation of AERMOD-ISC outputs}

The simulated daily $\mathrm{SO}_{2}$ concentrations have been validated with measured data that exceed the KW-EPA threshold. The simulated concentration was compared with the corresponding observed concentrations in monthly basis during the peak period at the four AQMS locations at the Mutla, Jahra, Rabia and Mansouriya residential areas. The highest fifteen values measured each month in the simulated and the measured $\mathrm{SO}_{2}$ concentrations are compared to each other.

Table 2 illustrates the coefficient of determination $\left(\mathrm{R}^{2}\right)$ of the simulated daily $\mathrm{SO}_{2}$ concentration against the measured daily $\mathrm{SO}_{2}$ concentration at the four AQMS locations during each month's peak period. The model simulated concentration seemed to correspond reasonably accurately with the observed 
values except for the Mansouriya residential area $\left(\left(\mathrm{R}^{2}=0.5558\right)\right.$. It can therefore be deduced that the performance of the model could be interpreted as satisfactory. However, any discrepancy between the simulated and measured concentration is as a result of the contribution from other $\mathrm{SO}_{2}$ sources than the power stations, such as road traffic, industrial emissions, other power stations etc.

Table 2: Coefficient of determination $\left(\mathrm{R}^{2}\right)$ of the simulated daily $\mathrm{SO}_{2}$ concentrations against the measured daily $\mathrm{SO}_{2}$ concentrations.

\begin{tabular}{|c|c|c|c|c|c|}
\hline \multirow{2}{*}{ Months } & \multicolumn{5}{|c|}{ Locations } \\
\cline { 2 - 6 } & Mutla & Jahra & Rabia & Mansouria & Overall \\
\hline May & $\begin{array}{c}\text { Not } \\
\text { available }\end{array}$ & 0.8724 & $\begin{array}{c}\text { Not } \\
\text { available }\end{array}$ & 0.9621 & 0.9172 \\
\hline June & 0.8718 & 0.6972 & $\begin{array}{c}\text { Not } \\
\text { available }\end{array}$ & 0.7596 & 0.7762 \\
\hline July & 0.8871 & 0.9042 & $\begin{array}{c}\text { Not } \\
\text { available }\end{array}$ & 0.8755 & 0.8889 \\
\hline August & 0.7645 & 0.7023 & 0.7157 & 0.8645 & 0.7617 \\
\hline September & 0.9431 & 0.6873 & 0.8022 & 0.5558 & 0.7471 \\
\hline Average R $\mathrm{R}^{2}$ & 0.8666 & 0.7727 & 0.759 & 0.8035 & 0.8004 \\
\hline
\end{tabular}

\subsection{Simulated hourly $\mathrm{SO}_{2}$ concentration}

Fig. 5 illustrates the maximum hourly $\mathrm{SO}_{2}$ concentration distribution. Most of these values were recorded during May, June, July, August and September. This reason is that there is a high emission rate which is caused by high overall fuel consumption in both Doha East and Doha West. This in turn relates to the load

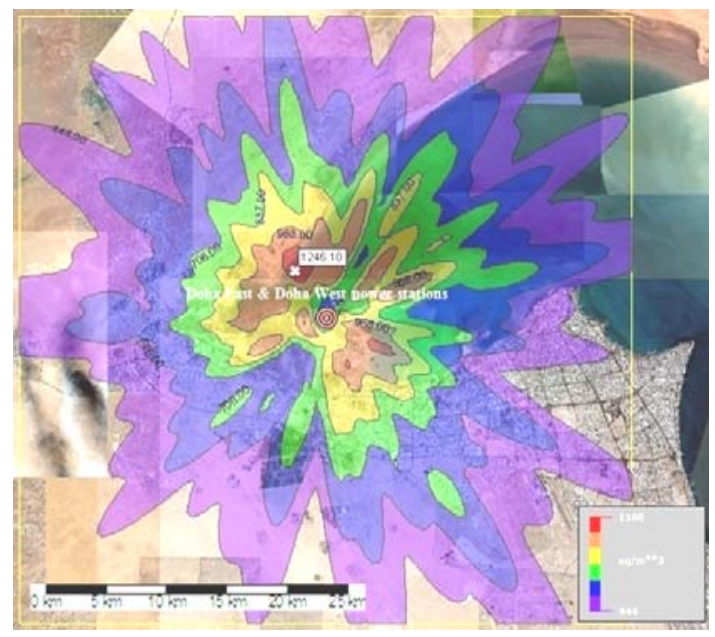

Figure 5: $\quad$ The maximum hourly $\mathrm{SO}_{2}$ concentration during 2008. 


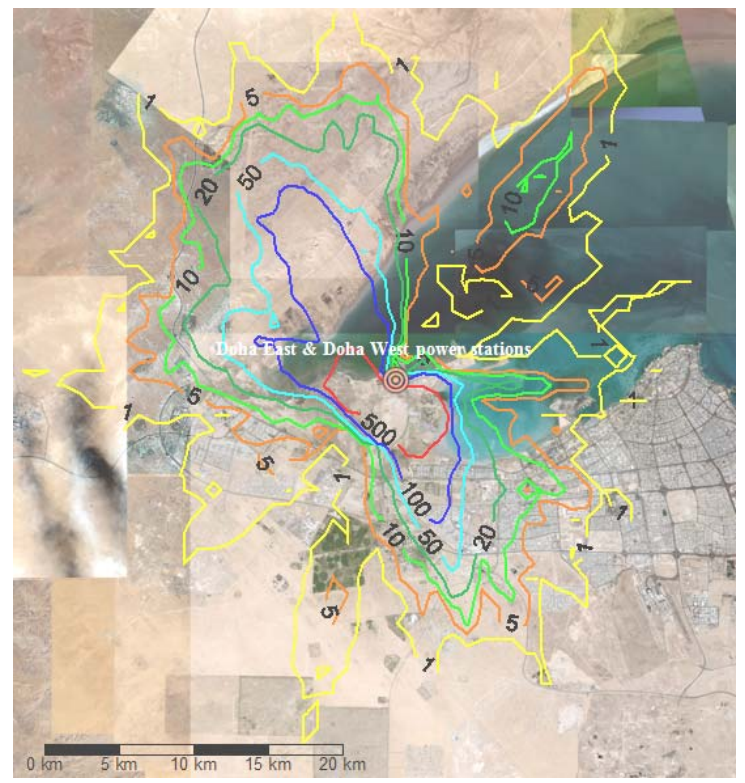

Figure 6: Contour lines represent the number of hourly $\mathrm{SO}_{2}$ violations during 2008.

during the peak period. Furthermore, these months are under unstable atmospheric conditions. Therefore, the vertical distribution of $\mathrm{SO}_{2}$ released from the stacks is very slow. It is clear that the $\mathrm{SO}_{2}$ concentration exceeded the $\mathrm{KW}$ EPA threshold of hourly $\mathrm{SO}_{2}$ concentration $\left(444 \mu \mathrm{g} / \mathrm{m}^{3}\right)$ over most of the residential areas. The highest simulated hourly $\mathrm{SO}_{2}$ concentration was 1246 $\mu \mathrm{g} / \mathrm{m}^{3}$, found on 31-Jul-2008, located to the northwest side, $4.6 \mathrm{~km}$ away from Doha East and Doha West power stations.

The distribution of the number of hourly $\mathrm{SO}_{2}$ violations at each point in the study area is represented by contour lines illustrated in Fig. 6. It is clear that most of the study area is exposed to hourly $\mathrm{SO}_{2}$ violations. The distribution of these violations is diffused northwest and southeast from the Doha East and Doha West power stations. This is due to the dominant wind directions in May, June, July, August and September which is the peak period. In addition, the frequency of these violations increases towards the Doha East and Doha West power stations.

\subsection{Simulated daily $\mathrm{SO}_{2}$ concentration}

Fig. 7 illustrates the maximum distribution of daily $\mathrm{SO}_{2}$ concentration. The highest simulated hourly $\mathrm{SO}_{2}$ concentration was $380 \mu \mathrm{g} / \mathrm{m}^{3}$ during June, $1.9 \mathrm{~km}$ towards the west of the power stations at Doha East and Doha West. Most of the maximum daily $\mathrm{SO}_{2}$ concentration appeared during the peak period, May, June, July, August and September. 


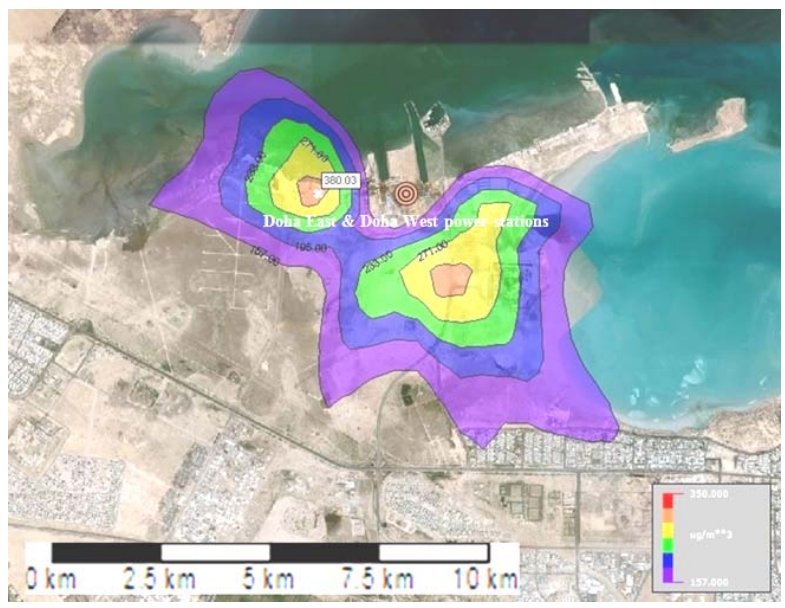

Figure 7: The maximum daily $\mathrm{SO}_{2}$ concentration during 2008.

According to the KW-EPA ambient air quality standards, the daily $\mathrm{SO}_{2}$ concentration should not occur more than once a year. The actual violated area is much smaller than the violated area in the simulated hourly $\mathrm{SO}_{2}$ concentration. It covers only a small part of both the Doha and Sulaibikhat residential areas.

\section{Conclusions}

The AERMOD-ISC model has been used to study the impact of $\mathrm{SO}_{2}$ emissions from the Doha East and Doha West power stations in Kuwait during year 2008. The validation of the simulated model was evaluated with the corresponding observed concentrations at the four AQMS locations. It was observed that the simulated $\mathrm{SO}_{2}$ concentrations are relatively close to those observed values. The model performance is also found to be satisfactory. The current study clearly indicates that there is a significant influence of $\mathrm{SO}_{2}$ emission on the Kuwait environment. The following conclusions can be made:

(a) $\mathrm{SO}_{2}$ concentrations exceeded the KW-EPA threshold of hourly $\mathrm{SO}_{2}$ concentration over most of the residential areas;

(b) Most of the maximum hourly $\mathrm{SO}_{2}$ concentrations occurred in May, June, July, August and September, which is the peak period;

(c) The hourly $\mathrm{SO}_{2}$ violations occurred over the peak period, and the majority of the violations during the peak period were distributed over June, July and August;

(d) A lot of residential areas were exposed to hourly $\mathrm{SO}_{2}$ violations;

(e) The most vulnerable residential areas are Doha, Qairawan and a part of Sulaibikhat;

(f) The distribution of the hourly and daily $\mathrm{SO}_{2}$ violations are diffused northwest and southeast from the Doha East and Doha West power stations. 


\section{References}

[1] Pruchnicki, J., Air Pollution Dispersion Models As Used In Poland In Regional Development Planning, Report the International Institute for Applied System Analysis. Poland, 1977.

[2] Patil S.B., Patil R.S. , Estimation of a quantitative air quality impact assessment score for a thermal power plant, Atmospheric Environment, 34B, 3, pp.443-448, 1990.

[3] Hosanna E., Aunela-Tapola L., Kinnunen V., Larjava K., Mehtonen A., Salmikangas T., Leskela J., Loosaar J., Emission factors and annual emissions of bulk and trace elements from oil shale fueled power plants, The Science of the Total Environment, 198, pp. 1-12, 19.

[4] Gouveiaa, C., Cerdeiraa, .R., Garciaa, J.M., Nogueirab, M. and Coelhoa, L.M.R., Numerical Modelling for Studying the Impact of Urban Air Pollution in Natural Reserves around Setúbal City. IEMSS Conference, 2004.

[5] Villegas, L.M.T., Cervantes, T.M.G., Gómez, I.R., Bravo G.V., Zuk, M., Bracho, R.L. and Bremautz, F.A., Evaluating The Impacts Of Power Plant Emissions In Mexico. 9th Int. Conf. on Harmonisation within Atmospheric Dispersion Modelling for Regulatory Purposes, 1-4 June, Germany, pp.385389, 2004.

[6] Palau, J.L., Pérez-Landa, G., Meliá, J., Segarra, D., and Millán, M.M., A Study Of The Dispersion Of A Power Plant Plume On Complex Terrain Under Winter Conditions In The Iberian Peninsula. EMS Annual Meeting Abstracts, Vol. 1, 00389, 2004.

[7] Bhanarkar, A.D., Rao, C.C.V. and Pandit, V.I., Air pollution modeling for power plant site selection. International Journal of Environmental Studies, Volume 62, Number 5, October, pp. 527-534(8), 2005.

[8] Lopez M.T., Zuk M., Garibay V., Tzintzun G. Iniestra R., Fernandez A., Health impacts from power plant emissions in Mexico" Atmospheric Environment 39, pp.1199-1209, 2005.

[9] Rodriguez M.A., Carreras-Sospedra, Medrano M. Brouwer J., Samuelsen G.S., Dabdub D., Air quality impact of distributed power generated in the south coast air basin of California 1: Scenario development and modeling analysis” Atmospheric Environment 40, pp.5508-5521, 2006.

[10] Racoceanu, C. and Diaconu, B.M., Study of Pollutants Dispersion Resulting From Lignite Combustion In Power Generation. Annals of the University of Craiova, Electrical Engineering series, No. 30, pp.208-21, 2006.

[11] Racoceanu, C. and Capatina, C., Cross-Boundary Pollution Due To The Activity Of A Thermal Power Station. Journal of the University of Chemical Technology and Metallurgy, 41, 1, pp. 103-106, 2006.

[12] Yousif, S.A., Salem, A.A., Nassar, Y.F. and Bader, I.F., Investigation of pollutants dispersion from power stations. International journal of energy research, vol. 30, no15, pp. 1352-1362, 2006. 
[13] Khlaifi, A., Ionescu, A. and Candau, Y., Pollution source identification based on a Gaussian model of dispersion coupled with a genetic algorithmapplication in a real industrial area of the greater Paris. International Conference on Approximation Methods and Numerical Modeling in Environment and Natural Resources, Granada (Spain), July 11-13, 2007

[14] Demael, E. and Carissimo, B., Local Atmospheric Dispersion Modelling Of Trace Constituents Issued From Nuclear Power Plant: A Comparison Using A CFD and ADMS with Wind Tunnel Data. Geophysical Research Abstracts, Vol. 9, 09662, 2007.

[15] Kho, W. L., Sentian, J., Radojevi, M., Tan, C. L., Law, P. L., \& Halipah, S., Computer simulated versus observed $\mathrm{NO}_{2}$ and $\mathrm{SO}_{2}$ emitted from elevated point source complex. 4 (2): 215-222, 2007.

[16] Yousefi, H., Ehara, S. and Noorollahi, Y., Air Quality Impact Assessment of Sabalan Geothermal Power Plant Project, NW Iran. Thirty-Third Workshop on Geothermal Reservoir Engineering Stanford University, Stanford, California, January 28-30, SGP-TR-185, 2008.

[17] Tuaycharoen, P., Wongwises, P., Pan-Aram, R. and Satayopas, B., Nitrogen Oxide (NOx) Dispersion Model for Khanom Power Plant Area. International Conference on Environmental Research and Technology. pp.653-657, 2008.

[18] Bouhamra, W.S. and Abdul-Wahab, S.A., Description of outdoor air quality in a typical residential area in Kuwait, Environmental Pollution 105, pp.221-229, 1999.

[19] Ramadan, A.A., Al-Sudairawi, M., Alhajraf, S. and Khan, A.R., Total $\mathrm{SO}_{2}$ Emissions from Power Stations and Evaluation of their Impact in Kuwait Using a Gaussian Plume Dispersion Model. American Journal of Environmental Sciences V.4, N. 1, pp. 1-12, 2008.

[20] Al-Azmi, B. N., Nassehi, V., \& Khan, A. (2008). Impact of emissions from power stations on the ambient air quality of selected urban areas in Kuwait. American Journal of Environmental Sciences. 